高度障害肝に対する脞ホルモンの有効性に関する基礎的研究

\title{
-Dimethylnitrosamine ラット硬変肝肝切除後の
}

\section{残存肝に対する荤ホルモンの有効性に関する実験的研究一}

\author{
奈良県立医科大学第 1 外科（指導：白鳥常男教授） \\ 吉川 高 志 \\ STUDIES ON THE EFFECT OF PANCREATIC HORMONE \\ ON SEVERE LIVER DAMAGE \\ -EXPERIMENTAL STUDIES ON THE EFFECT OF PANCREATIC HORMONE \\ ON THE DIMETHYLNITROSAMINE-INDUCED CIRRHOTIC \\ LIVER OF RATS FOLLOWING HEPATECTOMY-
}

Takashi YOSHIKAWA

First Department of Surgery, Nara Medical University

(Director: Prof. Tuneo Shiratori)

硬変肝肝切除後の残存肝の機能賦活ならびに再生を促進させる治療法を探究する目的で, Dimethylnitrosamine ラット硬变肝を作製し，その病態を検索するととるに, 70\%肝切除を行い, Insulin 0.5 $\mathrm{U} / \mathrm{kg} /$ day および Insulin $4 \mathrm{U} / \mathrm{kg} /$ day + Glucagon $2 \mathrm{mg} / \mathrm{kg} /$ day を門脈内に持続投与してその効果を 検討した。肝組織学的検索, 肝 ATP 含量および血液生化学検索からは両組成液の効果はみられず, DNA 合成能から Madden の Grade (1+) およびGrade (2+) で Insulin 0.5U/kg/day が，Grade (2+) でInsulin $4 \mathrm{U} / \mathrm{kg} /$ day+Glucagon $2 \mathrm{mg} / \mathrm{kg} /$ day がそれぞれ有意の再生促進効果を示し，また 肝切除後の生存率においても両組成液が Grade $(2+)$ で良好な成績を示した。このことは両組成液が 硬変肝肝切除後の有効な術後療法となることを示唆するものである.

索引用語 : Dimethylnitrosamine 硬変肝, 硬変肝肝切除, 肝切除後肝再生, Insulin 門脈内補充療法, Glucagon 門脈内補充療法

\section{I. 緒 䡒}

最近, 各種画像診断法の進歩 ${ }^{1) ~ 3)}$ 特よびAFPなどに よる血清スクリーニング4)5! とよって小さな肝癌の発 見が比較的容易となり,肝切除症例す増加しているが, その多くは併存する肝硬変のため治療成績は必ずしも 良好とはい学ない(6). 確かに, 肝予備能検查などの進歩 による術前の病態に即した肝切除量の決定や7)8 , かな り適切な術後療法が行なわれるよらになってきてはい るが9) 12), 肝臓癌の根治的治療という面からみればこ れらはいまだ不充分なものであり, 肝切除後には残存

$<1985$ 年 5 月 15 日受理 $>$ 別刷請求先 : 吉川 高志

T634 椳原市四条町840 奈良県立医科大学第 1 外科
能を賦活して術後肝不全を予防し，また残存肝の再生 を促進し，ひいては肝切除量を増大して根治性を高め らる治療法の開発が要求されている.

近年, この目的に沿って門脈内因子 ${ }^{13)}$ 18) に関する多 くの研究がなされており，特に苏ホルモンであるInsulin, Glucagon には有効性が認められ臨床的にも応 用されている(19). 著者はこの Insulin, Glucagon の効果 に注目し D-galactosamine (以下 Gal-N と略す) ラッ 卜障害肝の再生には Insulin $0.5 \mathrm{U} / \mathrm{kg} / \mathrm{day}$ の門脈内 持続投与が最す有効であることを実験的に証明しすで に報告した ${ }^{20)}$.

本実験ではひきつづいて Dimethylnitrosamine（以 下 DMN と略す) ラット硬变肝を作製し，その硬変肝 
の病態を検索するとともに, Insulin $0.5 \mathrm{U} / \mathrm{kg} / \mathrm{day}$ お よび Insulin $4 \mathrm{U} / \mathrm{kg} /$ day + Glucagon $2 \mathrm{mg} / \mathrm{kg} /$ day を 肝切除後に門脈内に持続投与して, その残存肝に対す る機能賦活および再生促進効果と肝庇護作用を検討す ることを目的として実験を行い，若干の知見を得たの で報告する。

\section{DMN 硬変肝の病態}

\section{A. 実験方法}

\section{1. 実験動物の作製}

実験動物として, DMN 硬変肝の作製には体重 180 220g の Wistar 系雄性ラットを, 正常肝の対照群 （以下対照群）には体重220 250g の Wistar 系雄性 ラットを用い,ともに日本クレア製標準固型飼料で飼 育した。

DMN 硬変肝は Haney らの方法 ${ }^{21}$ に準じてDMN (半井化学薬品)を正常飲料水に $1,000 \mathrm{ppm} の$ 割合で溶 解し, 体重 $100 \mathrm{~g}$ あたり $1.0 \mathrm{ml}$ の割合で 4 週間にわたっ て，週に 3 日間連続して金属性胃管を用いて経口投与 することにより作製した． 経口投与終了後 4 週間の休 薬期間をおいた後に硬変肝モデルとして実験に供し た.

DMN 硬変肝群および対照群に Anderson-Higgins の方法 ${ }^{22} に$ 基づいて70\%肝切除を行い, 肝切除後 2 日 目に屠殺して以下の検索を行った。

\section{2. 検索方法}

肝切除時に採取した肝で, 肝の病理組織像および肝 ATP 含量を検索した. 肝切除後 2 日目の屠殺時に採 取した肝で, 肝 ATP 含量およびDNA 合成能を検索 し, さらに屠殺時に採取した血液で血液生化学的検索 を行った。

\section{a. 病理組織学的検索}

肝切除時採取した肝を，10\%ホルマリンで固定し， HE染色とAzan-Mallory染色を行った。 そして， DMN 硬変肝の障害度を Madden の Histological Grading ${ }^{23)}$ に基づいて 4 つの Grade に分類した。

\section{b. 肝 ATP 含量}

肝切除時および肝切除後 2 日目に, ラットをエーテ ル浅麻酔下に開腹し, 肝を液体空素でよく冷却したス テンレススチール製のプレート付鉗子ではさみとり， すばやく液体窒素を満たした磁製乳ばち内へ沈めでき る限り細かく破碎した。この破砕した肝の重量を測定 した後, Potter-Elvehjem 型ガラスホモジナイザーで $6 \%$ Perchloric acid (以下 PCA と略す) を加えてホ モジネートした. そして, 再度肝重量を測定した後
$0{ }^{\circ} \mathrm{C} 10,000 \mathrm{rpm}$ で15分間遠心分離して得た上清を, $69 \% \mathrm{~K}_{2} \mathrm{CO}_{3}$ でメチルオレンジを指示薬として滴定し た.さらにこれを $0{ }^{\circ} \mathrm{C} 10,000 \mathrm{rpm}$ で 5 分間遠心分離し て得た上清をヌクレオチド抽出液とした。

ATP 含量の測定は, Lamprecht-Tautschold の方 法 ${ }^{24)}$ で酵素学的に分光光度計（日立製 Model 356）で 測定した。

c. 肝 DNA 合成能 (DNA specific activity)

肝切除後 2 日目に, ラットの腹腔内に ${ }^{3} \mathrm{H}$-thymidine $1 \mu \mathrm{Ci} / \mathrm{g}$ 体重を投与し， 1 時間後に屠殺して肝を $1 \mathrm{~g}$ 採 取した。

DNA の分画抽出は Scott の変法 ${ }^{20125)}$ に準じて行っ

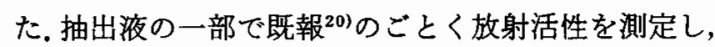
他の一部でDNA の定量をDiphenylamine 法 $^{26}$ によ り行った.

抽出液中のカウント数をDNA 量で除して比活性 $(\mathrm{cpm} / \mu \mathrm{g} \mathrm{DNA})$ を求め, DNA 合成能を表わす指標と した.

\section{d. 血液生化学的検索}

肝切除後 2 日目にラットをエーテル浅麻醉下に開腹 して, 下大静脈より血液を採取し, 血清 GOT, GPT (ライトマンーフランケル法), 血清 Albumin (BCG 法)を測定した。

\section{B. 実験成績}

1. DMN 硬変肝の病理組織像

DMN を投与したラットの総数は44匹であるが，肝 切除施行時まで生存したラットは15匹（34\%）であっ た。 その病理組織像は図 1 に示したように Maddenの Histological Grading ${ }^{231}$ に従って分類し, 図 1-A のよ らな所見のものをGrade (1+), 図 1-Bのような所見 をGrade (2+), 図 1-Cのような所見のものを Grade （3十）とした。また，図1-Dのような所見のものを Grade (4+) としたが, このような Grade (4+) の肝 組織像は肝切除時まで生存したラットではみられず, 肝切除時までに死亡したラットの剖検肝で得られた。

肝切除時玉で生存したラット15匹の肝硬変の程度 は, Grade $(1+)$ が 5 匹, Grade $(2+)$ が 4 匹, Grade (3+）が 6 匹であった。

なお，肝切除時の肝組織像が Grade (3+)であった 6 匹には肝切除後 2 日目まで生存したるのはいなかっ た.

\section{2. 肝 ATP 含量}

肝切除時および肝切除後 2 日目の肝 ATP 含量の值 は図 2 のごとく，それぞれ対照群が2.386士0.246 
図 1 DMN 硬変肝の障害度別病理組織像

Grade (1+)：図Aのごとく，好中球，リンパ球を主 体とする炎症性細胞漫潤および focal necrosis が認 められるが，肝細胞索はよく保たれ，線維化もみら れない $(\mathrm{HE}, \times 100)$

Grade $(2+)$ : 図Bのごとく, 線維の増加を認め, 中 心静脈一グ鞘, 中心静脈一中心静脈間に bridge 形成 がみられるが，偽小葉の形成には至っていない，正 常の小葉構造は失われているが，炎症反応は認めな い. $(\mathrm{HE}, \times 200)$

Grade $(3+)$ : 図Cのごとく, 線維性隔壁は為小葉 を形成しており，肝硬変の初期像である。（HE, × 200)

Grade (4+)：図Dのごとく，線維性隔壁は幅広く， 肝細胞は变性壊死傾向が強い, 再生結節を認め進行 した肝硬変像である。（HE，×200）
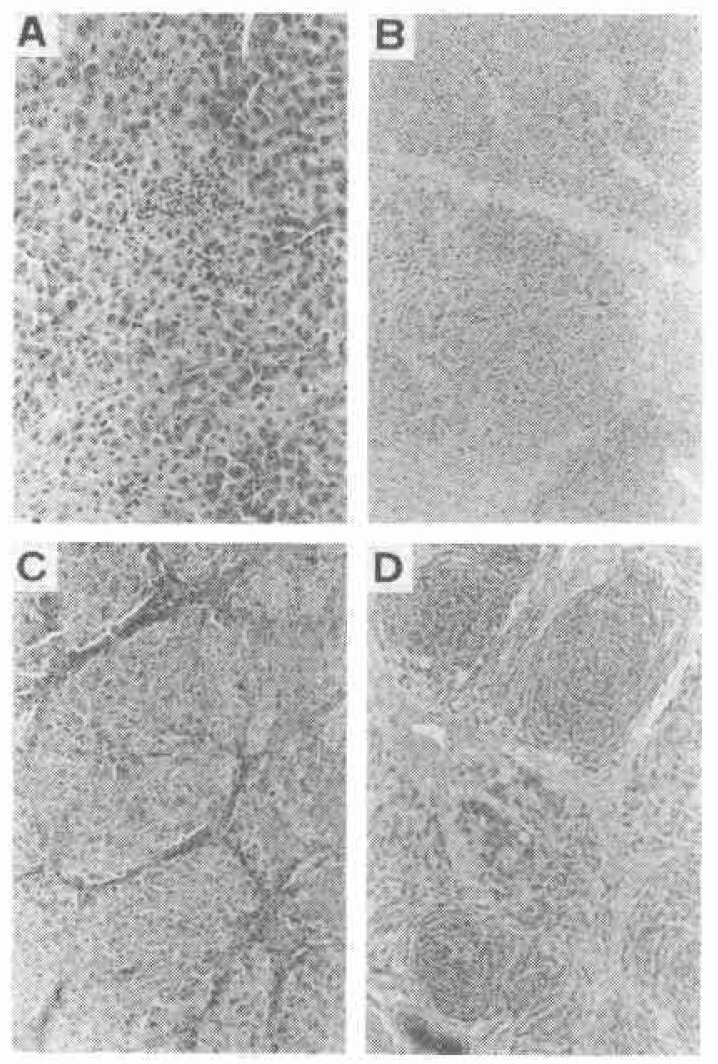

$\mu \mathrm{mole} / \mathrm{g} . \mathrm{LW}, 2.002 \pm 0.179 \mu \mathrm{mole} / \mathrm{g}$. LW, Grade $(1+)$ か $1.557 \pm 0.257 \mu$ mole $/ g . L W, \quad 1.036 \pm 0.143$ $\mu$ mole $/ g . L W$, Grade (2+) が1.354 $0.112 \mu$ mole $/ \mathrm{g}$. LW, $0.784 \pm 0.186 \mu \mathrm{mole} / \mathrm{g}$. LW, Grade (3+) の肝切 除時が $1.114 \pm 0.232 \mu \mathrm{mole} / \mathrm{g} . \mathrm{LW}$ であった.

肝切除時の肝 ATP 含量は, 対照群が最も高値で,

\section{図 2 肝 ATP 含量}

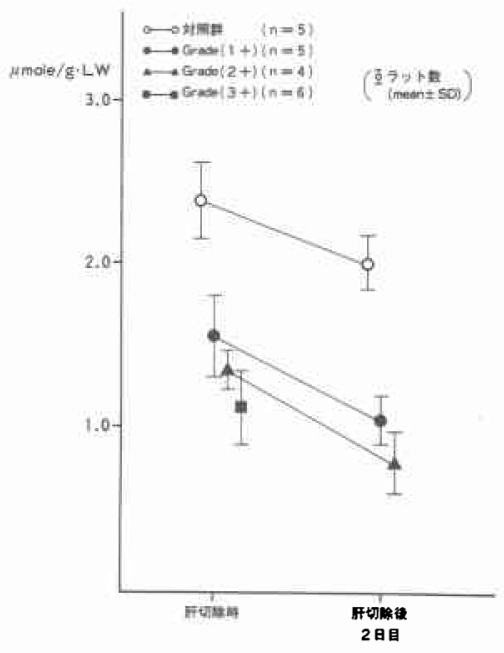

Grade $(1+)$, Grade $(2+)$, Grade (3t) と肝障害の 進行に比例して减少する傾向を示した。すなわち対照 群と Grade (1+)の間, 㧊よび Grade $(1+)$ と Grade $(3+)$ の間にそれぞれ有意差 $(\mathrm{p}<0.01, \mathrm{p}<0.01)$ を認 めたが, Grade $(1+)$ とGrade $(2+)$ の間, および Grade $(2+)$ とGrade (3+) の間には有意差を認めな かった.

また, 肝切除後 2 日目の肝 ATP 含量も, 対照群が最 も高值で, Grade (1+), Grade (2+) と肝障害の進行 に比例して有意の減少を示した。すすなわち，対照群と Grade $(1+)$ の間, および Grade $(1+)$ と Grade $(2+)$ の間にそれぞれ有意差 $(\mathrm{p}<0.01, \mathrm{p}<0.1)$ を認めた。

肝 ATP 含量は各群いずれも肝切除後 2 日目の値が 肝切除時に比べ減少する傾向を示した。 その減少は Grade (1+) とGrade (2+) でそれぞれ有意 $(\mathrm{p}<0.1$, $\mathrm{p}<0.02)$ であったが，対照群では有意ではなかった。

3. 肝 DNA 合成能 (DNA specific activity)

DNA specific activityは図 3 のごとく, 対照群が $78.4 \pm 6.75 \mathrm{cpm} / \mu \mathrm{g}$ DNA, Grade $(1+)$ が $43.81 \pm$ $16.07 \mathrm{cpm} / \mu \mathrm{g}$ DNA, Grade (2+) が41.57 17.95 $\mathrm{cpm} / \mu \mathrm{g}$ DNAであり, 対照群に比べ, Grade (1+), Grade $(2+)$ の 2 群はそれぞれ有意 $(\mathrm{p}<0.01, \mathrm{p}<$ $0.01)$ 低值を示した. しかし, Grade (1+)と Grade （2+）の間には有意差を認めなかった。

4. 血液生化学的検索

a. 血清 GOT 值

血清 GOT 值は図 4 左のごとく，対照群が，120.6士 12.8K.U., Grade (1+) が249.8 \pm 40.9 K.U., Grade 
目 3 DNA specific activity

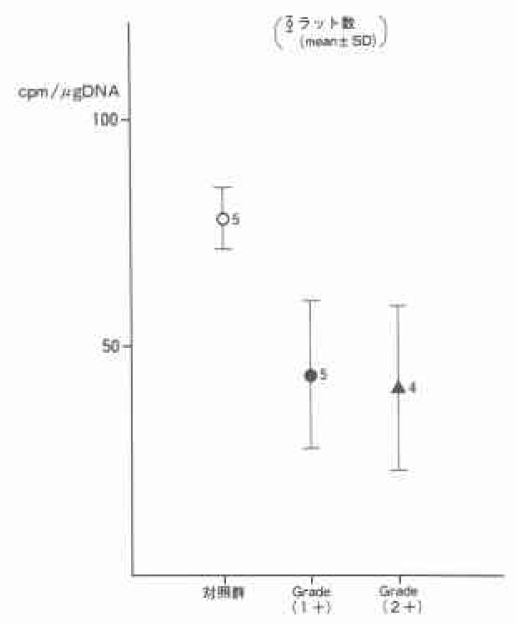

図 4 血清 GOT, GPT 拈上び血清 Albumin 值

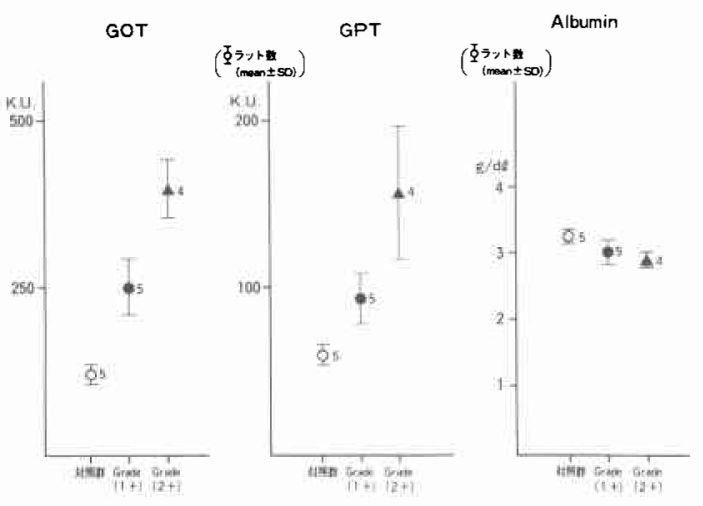

(2+) が397.6士45.8K.U.であり，対照群が最も低値 で, Grade $(1+)$, Grade $(2+)$ と肝障害の進行に比例 して有意の増加を示した。すなわち, 対照群と Grade $(1+)$ の間，おょび Grade (1+) と Grade $(2+)$ の間 にそれぞれ有意差 $(\mathrm{p}<0.01, \mathrm{p}<0.01)$ を認めた。

b. 血清 GPT 値

血清 GPT 值は図 4 中央のごとく，対照群が62.8土 7.4K.U., Grade (1+) が92.7士14.5K.U., Grade (2+) が156.1土40.9K.U.であり, 血清 GOT 值と同様, 対照 群が最す低値で, Grade (1+), Grade $(2+)$ と肝障害 の進行に比例して有意の増加を示した。すなわち，対 照群と Grade (1+) の間, および Grade $(1+)$ と Grade $(2+)$ の間にそれぞれ有意差 $(\mathrm{p}<0.01, \mathrm{p}<$ 0.05)を認めた.

c. 血清 Albumin 値

血清 Albumin 值は図 4 右のごとく, 対照群が3.27士
$0.07 \mathrm{~g} / \mathrm{dl}$, Grade $(1+)$ が3.01 $\pm 0.19 \mathrm{~g} / \mathrm{dl}$, Grade $(2+)$

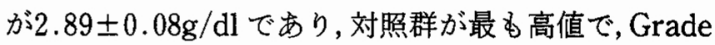
$(1+)$, Grade (2+) と肝障害の進行に比例して减少す る傾向を認めた。すなわち, 対照群と他の 2 群の間に はそれぞれ有意差（p<0.05, p<0.01）を認めたが, Grade $(1+)$ と Grade $(2+)$ の間には有意差を認めな かった。

III. DMN 硬変肝における肝切除後の残存肝に 対する Insulin, Glucagon の効果

A. 実験方法

1. 実験動物の作製

実験動物には体重180 220g の Wistar 系雄性ラッ 卜を用い, DMN 硬変肝モデルを前節 II と同じく Haney らの方法 ${ }^{21}$ に準じて DMN を投与して作製し， 実験に供した。

この DMN 硬変肝を Anderson-Higgins の方法 ${ }^{22)} に$ 基ついて70\%肝切除し, 同時にシラスコンチューブ(ダ ウコーニング社製, size 0.5〜1.0mm) の先につけた $26 \mathrm{G}$ 皮内針を門脈本幹に直接刺入し外科用接着剂了口 ンアルファAで固定した. 同チューブを皮下を通じて 背部より体外へ導出し, Cannular free through Swivel を用いて持続注入ポンプ(シャープ製 PIP21, MP21）に接続した。

このように処置したラットを，10\%glucose（基碟 液）のみを注入する群 (I 群=対照群), Insulin 0.5U/ $\mathrm{kg} /$ day $10 \%$ glucose に溶解して注入する群（II 群）, Insulin $4 \mathrm{U} / \mathrm{kg} / \mathrm{day}+$ Glucagon $2 \mathrm{mg} / \mathrm{kg} /$ day $10 \%$ glucose に溶解して注入する群 (III 群) の3つの群に 分けて, 各組成液を肝切除直後より48時間にわたって 屠殺するまで，5ml/24時間の割合で門脈内へ持続投与 した.

そして, 前節 II と同様, 3 群のラットの肝切除時の 肝組織像を Madden $の$ Histological Grading ${ }^{23)}$ に基 ついて 4 つの Grade に分類し以下の検索を行った。

2. 検索方法

a. 病理組織学的検索

肝切除時および肝切除後 2 日目にラットを屠殺した 時に採取した肝を，前節 II と同様，10\%ホルマリンで 固定し, HE 染色と Azan-Mallory 染色を行った. そし て, 4 つの Grade 別に DMN 硬変肝の肝切除前後の障 害度の変化を検討した。

b. 肝 ATP 含量

肝切除時拉よび肝切除後 2 日目に, 前節 II と同じ方 法で測定した。 
c. 肝 DNA 合成能 (DNA specific activity)

肝切除後 2 日目に, 前節 II と同じ方法で測定した。

d. 血液生化学的検索

肝切除後 2 日目に, 前節 II と同じ方法で, 血清 GOT, GPT 抽よび Albumin 值を測定した。

e. 肝切除後の生存率

生存率は肝切除を行ったラット数で, 肝切除後 2 日 目の屠殺時まで生存したラット数を除して求めた。

B. 実験成績

1. 病理組織学的検索

a. DMN 硬変肝の病態

DMN の投与を行ったラットの総数は274匹である が，肝切除施行時をで生存したラットは92匹(33.5\%) であった。しかし，その92匹のうら18匹に術死抢よび 組成液の注入不足があり，肝切除時に硬変肝モデルと して実験に供したのは74匹である。この74匹をI群(対 照群)に29匹，II 群に25匹，III 群に20匹とそれぞれふ りわけた。

この 3 群の硬変肝の障害度は，I群（対照群）では Grade $(1+)$ が10匹, Grade $(2+)$ が12匹, Grade $(3+)$ が 7 匹，II 群では Grade (1+) が10匹, Grade $(2+)$ が11匹, Grade (3+) が 4 匹, III 群では Grade (1+) が 4 匹, Grade $(2+)$ が 9 匹, Grade $(3+)$ が 7 匹で あった。前節 II と同様, Grade (4+)の肝組織像は肝 切除時まで生存したラットではみられなかった。

b. 肝切除前後の肝組織像の変化

実験に供された74匹のラットのうち，肝切除後，2 日目まで生存したのは44匹であった。

そこで, この44匹について肝切除後の肝組織像の変 化を検討したが，肝切除時の肝組織像はすべて Grade （1+）㧍よびGrade (2+) であり， I 群 (対照群) で は Grade (1+) が10匹, Grade (2+) が 6 匹, II 群で は Grade (1+) が10匹, Grade (2+) が 8 匹, III 群 では Grade (1+) が 4 匹, Grade (2+) が 6 匹であっ た.な拉, 肝切除時の肝組織像が Grade $(3+)$ のラッ トには肝切除後 2 日目まで生存したものはいなかっ た.

肝切除後 2 日目の残存肝は, Maddenの Histological Granding ${ }^{23)}$ からみると, 图 5 のように Grade (1+), Grade (2+) のいずれに打いても3 群と る肝切除時より肝障害が進行する傾向を認めたが，そ の進行の程度には 3 群の間に有意差を認めなかった。 なお, 以下の肝 ATP 含量, 肝 DNA 合成能および血 液生化学的検索は，この44匹のうちの一貫した観察を
図 5 肝切除前後の肝組織像の変化

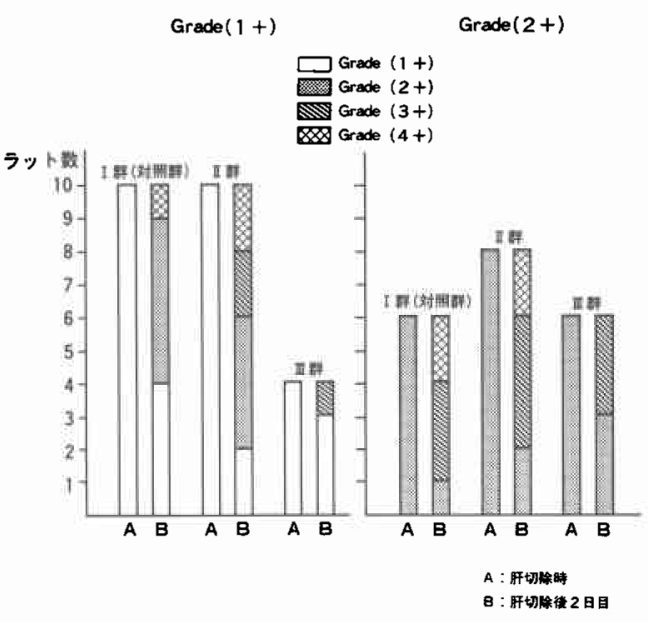

行い得た23匹を対象として検討された。すなわち，I群 (対照群) では Grade (1+) が 4 匹, Grade $(2+)$ が 4 匹, II 群では Grade (1+) が 5 匹, Grade (2+)が 4 匹, III 群では Grade (1+) が 3 匹, Grade (2+) が3匹である.

\section{2. 肝 ATP 含量}

肝切除時および肝切除後 2 日目の肝 ATP 含量の値 は図 6 のごとく，Grade（1+）のものでは，それぞれ

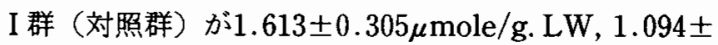
$0.162 \mu \mathrm{mole} / \mathrm{g}$. LW, II 群 LW, $0.831 \pm 0.164 \mu \mathrm{mole} / \mathrm{g}$. LW, III 群が, $1.472 \pm$ $0.058 \mu \mathrm{mole} / \mathrm{g}$. LW, $1.286 \pm 0.235 \mu \mathrm{mole} / \mathrm{g}$. LW で あった. Grade (2+)のものでは，それぞれI群(対照 群) が $1.387 \pm 0.090 \mu \mathrm{mole} / \mathrm{g} . \mathrm{LW}, 0.799 \pm 0.188$

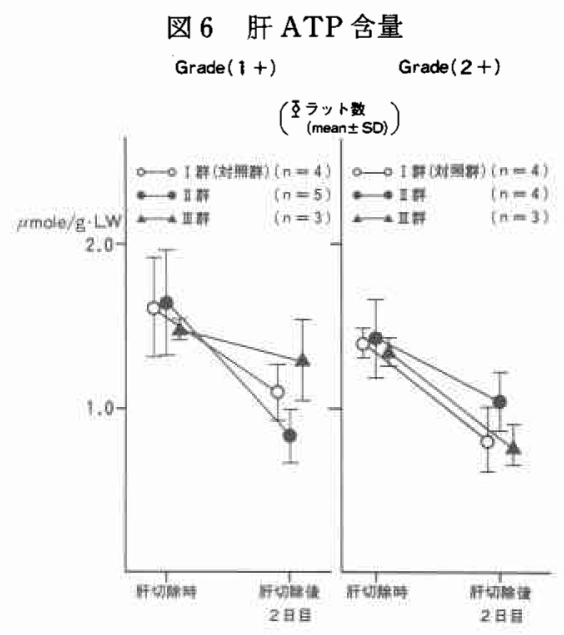


$\mu \mathrm{mole} / \mathrm{g}$. LW, II 群 が1.410 $\pm 0.233 \mu$ mole/g. LW, $1.032 \pm 0.171 \mu \mathrm{mole} / \mathrm{g} . \mathrm{LW}$, III 群が $1.328 \pm 0.083$ $\mu \mathrm{mole} / \mathrm{g}$. LW, $0.767 \pm 0.113 \mu$ mole/g. LW であった.

肝切除時の肝 ATP 含量は, Grade (1+), Grade (2+）のいずれに执いても 3 群の間に有意差を認めな かった.

肝切除後 2 日目の肝 ATP 含量は, Grade $(1+)$ の わのでは，I群 (対照群) と III 群が，II 群に比べそれ ぞれ有意 $(\mathrm{p}<0.1, \mathrm{p}<0.05)$ に高値であったが, I 群 （対照群）とIII 群の間には有意差を認めなかった。 Grade (2+) のものでは， 3 群の間に有意差を認めな かった.

肝 ATP 含量は, 肝切除後 2 日目の值が肝切除時に 比べ減少する傾向をいずれの群でも認めた，その減少 は, Grade (1+) の I 群 (対照群), II 群, Grade (2+) のI 群 (対照群), II 群, III 群でそれぞれ有意 $(\mathrm{p}<0.1$, $\mathrm{p}<0.02, \mathrm{p}<0.02, \mathrm{p}<0.1, \mathrm{p}<0.02)$ であったが, Grade (1+) の III 群では有意ではなかった。

3. 肝 DNA 合成能 (DNA specific activity)

DNA specific activityは図 7 のとく, Grade

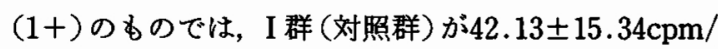

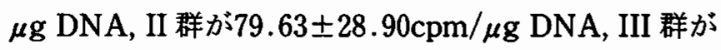
$44.09 \pm 12.04 \mathrm{cpm} / \mu \mathrm{g}$ DNA であり, II 群が I 群(対照 群) に比べ有意（p<0.1）に高値であったが，I群（対 照群)と III 群の間および II 群と III 群の間には有意差 を認めなかった。

Grade (2+) のものでは, I 群 (対照群) が41.23土 $18.91 \mathrm{cpm} / \mu \mathrm{g}$ DNA, II 群 が $90.97 \pm 25.83 \mathrm{cpm} / \mu \mathrm{g}$ DNA, III 群が88.73 $110.14 \mathrm{cpm} / \mu \mathrm{g}$ DNA であり, II

㘣 7 DNA specific activity

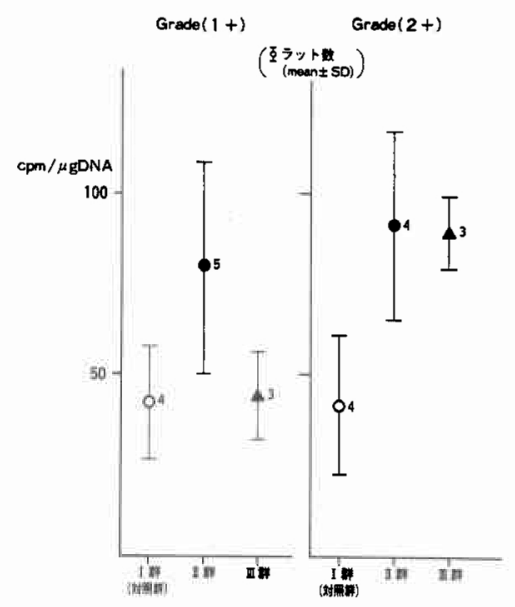

群と III 群が，I 群 (対照群) に比べそれぞれ有意 $(\mathrm{p}<$ 0.05, p<0.05) に高値であったが, II 群と III 群の間に は有意差を認めなかった。

4. 血液生化学検索

a. 血清 GOT 值

血清 GOT 値は図 8 のごとく, Grade (1+)のもの

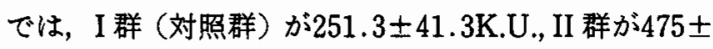
307K.U., III 群が266士141K.U.であり， 3 群の間には 有意差を認めなかった。

Grade (2+)のものでは, I 群 (対照群)が399土46.1

因 8 血清 GOT 値

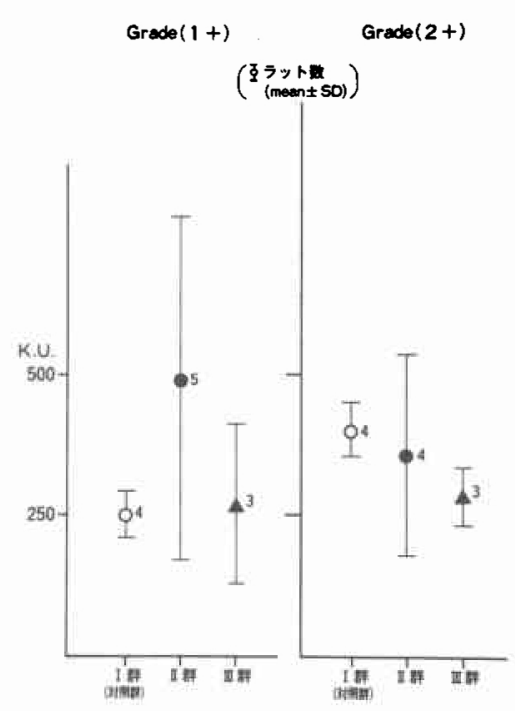

因 9 血清 GPT 值

$\operatorname{Grade}(1+) \quad \operatorname{Grade}(2+)$

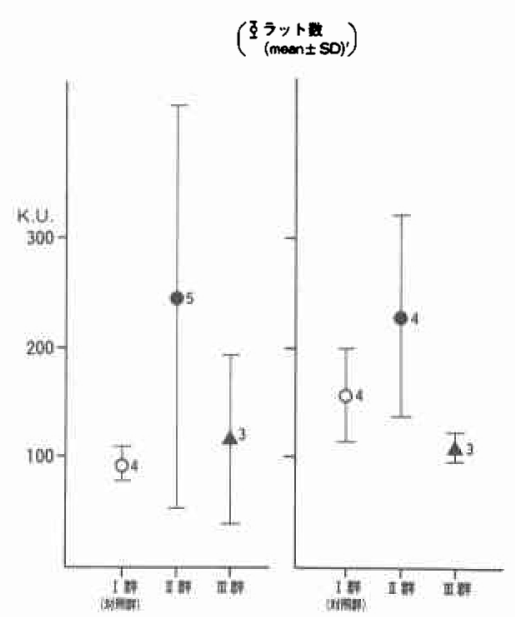


る促進的結果と肝細胞壊死抑制作用を報告している。 また, 硬変肝肝切除後にも, 本邦では両ホルモンが様々 な量や比率および方法で投与されているが9) 12)，未だ その投与方法は確立されていない。

実験的に, 硬変肝肝切除後に Insulin, Glucagon を投 与してその効果を検討した報告は少ない，長尾 ${ }^{35}$ は, Insulin, Glucagonを拉の扔の単独でDAB 硬変肝肝 切除後に大腿静脈より投与して, 両ホルモンが残存肝 の Energy 代謝拉よび核酸代謝障害の改善に有効で あったと報告している.

今回の著者の実験では, DMN硬変肝肝切除後に Insulin $0.5 \mathrm{U} / \mathrm{kg} / \mathrm{day}$ 括よび Insulin $4 \mathrm{U} / \mathrm{kg} / \mathrm{day}+$ Glucagon $2 \mathrm{mg} / \mathrm{kg} /$ day 門脈内に持続投与したが, 両組成液には Energy 代謝の賦活効果预よび肝庇護作 用は Maddenのどの Gradeでもみられなかった。し かし, 肝再生促進効果は Insulin $0.5 \mathrm{U} / \mathrm{kg} / \mathrm{day}$ には Grade (1+) 拉よび Grade (2+) において, Insulin $4 \mathrm{U} / \mathrm{kg} /$ day + Glucagon $2 \mathrm{mg} / \mathrm{kg} /$ day には Grade (2+) に扣いて認められ，両組成液の肝切除後のラッ

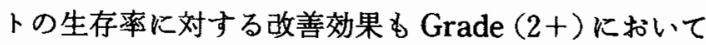
認めた。

Grade (3+) で Energy 代謝の賦活効果, 肝庇護作 用, 肝再生促進効果执よび肝切除後の生存率の改善が みられなかったことは, Grade (3+) を70\%肝切除し

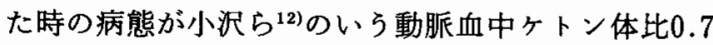
以下に相当するのではないかと思われ，そらであれば 彼らのケトン体比が 0.7 以下の症例には Insulin が無 効であるとの報告に合致する。

以上，本実験で Madden の Grade (2+) 以下（特に Grade $(2+))$ の肝組織像を呈するラットの $70 \%$ 肝切 除後において, Insulin $0.5 \mathrm{U} / \mathrm{kg} /$ day および Insulin 4 $\mathrm{U} / \mathrm{kg} /$ day + Glucagon $2 \mathrm{mg} / \mathrm{kg} /$ day が有効であり， Grade (3+) では無効であるとの結果は, 臨床面にお いて Grade $(2+)$ 以下の上5な併存肝病変をるつ肝癌 を切除した場合の術後療法として有効であり, 根治面 から70\%まで肝切除を桩大しても術後合併症を減少さ せらることを示唆するものである。

今後さらに, Insulin, Glucagon の量と比率, および 硬変肝の程度之肝切除量のかねあいによるInsulin, Glucagonの効果などを検討していきたいと考えてい る.

\section{V. 結 語}

DMN ラット硬変肝を作製し，その病態を検索する とともに, Insulin $0.5 \mathrm{U} / \mathrm{kg} /$ day 肪よび Insulin $4 \mathrm{U} /$ $\mathrm{kg} /$ day + Glucagon $2 \mathrm{mg} / \mathrm{kg} /$ day を70\%肝切除直後 より48時間にわたって門脈より持続投与して, 両組成 液の残存肝に対する効果を検討し，以下の結果を得た。

1. DMN 硬変肝は，Energy 代謝および核酸代謝の 両機能とも低下しており, 特に肝 ATP含量の值は Maddenの組織学的障害度の進行に比例して减少する 傾向を示した。 また, 組織学的障害度の進行に比例し て血清 GOT, GPT 值は高值を示し, 血清 Albumin 値 は低値を示す傾向を認めた。

2. 両組成液には, DMN 硬変肝肝切除後の残存肝に 対する機能賦活㧍よび肝庇護面での効果は, 肝組織学 的検索, 肝 ATP 含量および血液生化学的検索からみ られなかった. しかし，肝再生促進効果は, Insulin 0.5 $\mathrm{U} / \mathrm{kg} /$ day には Grade (1+) および Grade $(2+)$ に おいて, Insulin $4 \mathrm{U} / \mathrm{kg} /$ day + Glucagon $2 \mathrm{mg} / \mathrm{kg} /$ day にはGrade $(2+)$ に扔いて DNA 合成能から認めら れ，また両組成液の肝切除後の生存率に対する改善効 果もGrade $(2+)$ に拈いて認めた. 以上の結果から, 臨床面に括いて両組成液が, 残存肝の再生促進の目的 で, 硬変肝肝切除後の術後療法として応用しうる可能 性が示唆された。

稿を終るに臨み, 御指導, 御校閲を賜った白鳥常男教授, また直接御指導, 御援助いただいた深井泰俊助教授, 吉田英 晃博士に深謝する. また御支援，御協力をいただいた教室の 諸兄に謝意を表する。

本論文の要旨は第83回日本外科学会総会に括いて発表し た.

な报，本研究の一部は文部省科学研究費(No. 57770814) によってなされたことを付記する。

\section{文献}

1）大藤正雄, 品川 孝, 木村邦夫注か：超音波りニア 電子スキャンkよる小肝細胞癌の診断, とくに他 検查法との対比による診断能の検討. 肝贜 22 ： 119, 1981

2) 大上庄一, 大石 元, 黒崎喜久涪：細小肝細胞癌 のCT による検討. 画像診断 2:785-793, 1982

3）大石 元, 大上庄一, 今井幸子注：小肝細胞癌の 血管造影像に関する検討。日医放線会誌 42 ： $1-7,1982$

4）松本由朗, 麻田 勇, 鈴木 敞注か：血中 AFP 動 態からみた Hepatoma の臨床分類一AFP による Hepatoma の早期診断のための基礎的研究一. 肝 臓 $18: 847-855,1977$

5）安藤㤵次郎, 沖田 極, 渡辺精四郎注か：肝細胞癌 早期診断のための screening 法の検討一肝細胞癌 合併 high risk group 設定の試み一。肝葴 22 ： 1162-1169, 1982 
6）日本肝癌研究会：原発珄肝癌に関する追跡調查 一第 5 報一。肝葴 $23: 675-681 ， 1982$

7）小澤和恵, 山本正之, 戸部隆吉：肝癌の手術適応と 限界. 消外 2:1173-1182, 1979

8）水本龍二, 野口 孝, 中川 毅：肝機能予備力之手 術危険度の判定. 外科治療 $39: 71-78,1978$

9) 岡本英三, 山中若樹, 京 明雄: 肝切除後の管理. 消外 2:1207-1212, 1979

10）川原田嘉文: 術後一週間の患者管理一肝切除術. 臨外 $36: 539-545,1981$

11）平澤博之, 小高通夫, 大竹喜雄はか：われわれの行 なっている肝切除術後 critical stage の管理法. 消 外 $5: 349-355,1982$

12）小澤和恵, 田中純次, 山本正之ほか：肝切除後の術 後管理, 外科 Mook 31：113-122, 1983

13) Starzl TE, Halgrimson CG, Francavilla FR et al : The orign, hormonal nature, and action of hepatotrophic substances in portal venous blood. Surg Gynecol Obstet $137: 179-199,1973$

14) Price JB Jr, Takeshige $\mathrm{K}, \mathrm{Max} \mathrm{MH}$ et al: Glucagon as the portal factor modifying hepatic regeneration. Surgery $72: 74-82,1972$

15) Whittemore AD, Kasuya M, Voorhees $A B$ Jr et al: Hepatic regeneration in the abscence of portal viscera. Surgery $77: 419-426,1975$

16) Bucher NLR, Swaffield MN : Regulation of hepatic regeneration in rats by synergistic action of insulin and glucagon. Proc Nat Acad Sci USA 72: 1157-1160, 1975

17) Fisher B, Szuch P, Fisher ER : Evaluation of a humoral factor in liver regeneration utilizing liver transplants. Cancer Res 31:322-331, 1971.

18) Leffert HL: Growth control of differentiated fetal rat hepatocytes in primary monolayer culture. VII. Humoral control of DNA synthesis and its possible significance to the problem of liver regeneration. J Cell Biol 62:792-801, 1974

19）沖田 極, 相部 剛, 加屋 茂ほか：肝疾患治療薬 の作用に関する基礎的研究. (3). glucagon-insulin 療法による急性, 慢性肝不全の治療. 肝臟 19 : $854-861,1978$

20）吉川高志：高度障害肝に対する膵ホルモンの有効 性に関する基礎的研究-D-galactosamine ラット 障害肝に対する脺ホルモンの有効性に関する実験 的研究一。 日消外会誌 $16: 953-959,1983$

21) Haney A, Peacock EE Jr, Madden JW : Liver regeneration and hepatic collagen deposition in rats with dimethylnitrosamine-induced cirrhosis. Ann Surg $175: 863-869,1972$

22) Higgins GM, Anderson RM : Restoration of the liver of the white rat following partial surgical removal. Arch Pathol 12:186-202, 1931

23) Madden JW, Gertman PM, Peacock EE Jr: Dimethylnitrosamine-induced hepatic cirrhosis : A new canine model of an ancient human disease. Surgery $68: 260-268,1970$

24) Lamprecht W, Trautschold I: Determination with hexokinase and glucose-6-phosphate dehydrogenase. In: Method of enzymatic analysis. Edited by HU Bergmyer. New York, London, Academic Press, 1963, p2101-2110

25) Konishi $Y$, Denda A, Takahashi $S$ et al : Effect of chemical carcinogens on pancreatic DNA synthesis in vivo. Gann $67: 781-786,1976$

26) Burton $K$ : A study of the conditions and mechanism of the diphenylamine reaction for the colorimetric estimation of deoxyribonucleic acid. Biochem J $62: 315-323,1956$

27) Magee PN : Toxic liver injury. Inhibition of protein synthesis in rat liver by dimethylnitrosamine in vivo. Biochem J $70: 606-611$, 1958

28) Magee PN: Toxic liver injury. The metabolism of dimethylnitrosamine. Biochem J $64: 676-682,1956$

29）水田哲明：肝硬变の外科的治療に関する実験的研 究. 日外会誌 $82 ： 1236-1247,1981$

30) Ryser H, Frei J, Vannoti A : Enzymic studies in small amounts of human tissue with the help of microanalytical methods. III. Energetic metabolism of cirrhotic and precirrhotic liver tissue removed by needle biopsy. Clin Chim Acta 3 : 486-493, 1958

31) O'Donnel JF, Schiff L, Piller M : Acid-soluble nucleotides. J Lab Clin Med 59: 963-969, 1962

32) Pagliaro L, Notarbartolo A, Mannino V et al : Reduced ability of mitochondria isolated from liver tissue of patients with cirrhosis to synthes. ize ATP. J Lab Clin Med 62 : 184-192, 1963

33) Diaz Gil J, Rossi I, Escartin P et al: Mitochondrial functions and content of microsomal and mitochondrial cytochromes in human cirrhosis. Clin Sci Molec 52: 599-606, 1977

34）梅田政吉：実験的脂肪性肝硬変進展に伴ら代謝異 常にかんする研究. 第 1 編. 分離ラット肝ミトコン ドリアの呼吸調節能, 酸化的リン酸化について.日 消病会誌 $72: 1502-1510,1975$

35）長尾 桓：肝再生における辇ホルモンの有効性に 関する実験的研究. 日外会誌 $80: 685-700,1979$

36）桜井秀憲：肝大量切除後における残存肝細胞 ミ卜 コンドリアの動態. 特にエネルギー代謝とミトコ 
ンドリアDNAの複製について. 肝酮 17 : $158-169,1976$

37）中谷寿男, 小沢和恵, 浅野元和汪か：肝切除後の土 ネルギー基質の変化汇関する実験的研究. 日消外 会誌 $14: 1420-1426,1981$

38) Mann FC, Fishback FC, Green GF : Experimental pathology of the liver. Arch Pathol $12: 787-793,1931$

39) Cameron GR, Karunaratne WAE: Carbon tetrachloride cirrhosis in relation to liver regeneration. J Pathol Bacteriol 42 : 1-21, 1936

40) Kaufmann G: Tetrachlorkohlenstoff-zirrhose und restauration der leber. Beit Pathol Anat $113: 253-270,1953$

41) Islami AH, Pack GT, Hubbard JC: Regenerative hyperplasia of the cirrhotic liver following partial hepatectomy. Cancer $11: 663-686$, 1958

42) Ravinovici N, Wiener $\mathrm{E}$ : Liver regeneration after partial hepatectomy in carbon tetrachloride-induced cirrhosis in the rat. Gastroenterology $40: 416-422,1961$

43) Solopaev BP, Butnev YuP, Kuznetsova GG: Reparative regeneration of liver with experimentally induced cirrhosis. Biull Eksp Biol Med 51 : 74-79, 1961

44) Pechet G, MacDonald RA : Repair of nutritional cirrhosis, Autoradiographic and histological study after partial hepatectomy. Cancer $14: 963-970,1961$

45) Bengmark S, Olsson R, Rehnström B: The influence of partial hepatectomy in experimental nutritional cirrhosis in the rats. Acta Chir Scand 132: 112-128, 1966

46）舟木昭蔵: 実験的肝硬変の再生に関する研究. 北 海道医誌 $40 ： 139-150,1965$

47）白倉徹哉：肝切除後残存肝の再生肥大に関する実 験的研究及び臨床的知見. 日外会誌 $77: 1394$ $-1410,1976$

48) Starzl TE, Watanabe K, Porter KA et al: Effects of insulin, glucagon, and insulin/ glucagon infusions on liver morphology and cell division after complete portcaval shunt in dogs. Lancet II : 821-825, 1976

49) Starzl TE, Porter KA, Francavilla JA et al: A hundred years of the hepatotrophic contro. versy. Ciba Found Symp $55: 111-129,1977$

50) Stevenson RW, Parsons JA, Alberti KGMM : Insulin infusion into the portal and peripheral circulations of unanesthetized dogs. Clin Endocrinol $8: 335-347,1978$

51）小澤和恵, 山岡義生, 本庄一夫 : 肝再生と門脈血内 の因子、医のあゆみ $88 ： 283-288,1974$ 